\title{
Pulmonary arterial hypertension associated with connective tissue disease
}

INSERM

\section{Source}

INSERM. (1999). Orphanet: an online rare disease and orphan drug data base. Pulmonary arterial hypertension associated with connective tissue disease. ORPHA:275798

Pulmonary arterial hypertension (PAH, see this term) associated with connective tissue disease (PAH-CTD) is a form of pulmonary arterial hypertension (PAH, see this term) characterized by an elevated pulmonary arterial resistance leading to right heart failure observed as a complication of a connective tissue disease. 